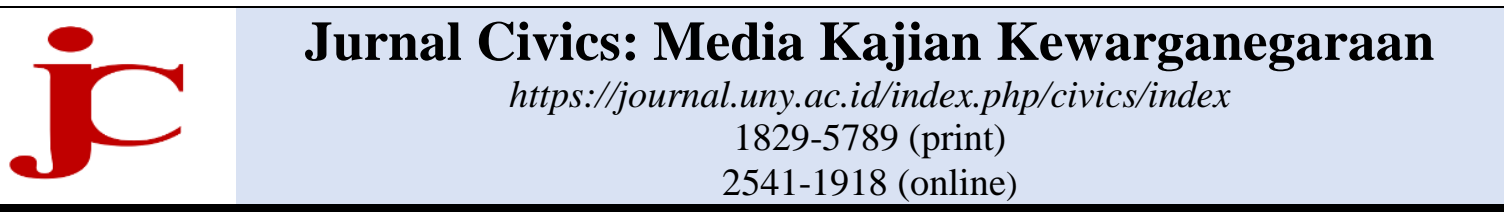

\title{
Implementasi pemenuhan hak anak melalui sekolah ramah anak
}

\author{
Wuri Wuryandani a,1, Fathurrohman b, 2, Anwar Senen ${ }^{3,}$, , Haryani d, 4 \\ a, b, c, d Fakultas Ilmu Pendidikan, Universitas Negeri Yogyakarta, Sleman, Indonesia \\ ${ }^{1}$ wuri_wuryandani@uny.ac.id*; ${ }^{2}$ fathurrohman@uny.ac.id; ${ }^{3}$ senen@uny.ac.id; ${ }^{4}$ haryani@uny.ac.id \\ *korespondensi penulis
}

\begin{tabular}{ll}
\hline \multicolumn{2}{l}{ Informasi artikel } \\
\hline Sejarah artikel: & \\
Diterima & $: 01-05-2018$ \\
Revisi & $: 30-05-2018$ \\
Dipublikasikan & $: 31-05-2018$ \\
\hline
\end{tabular}

Kata kunci:

Pemenuhan hak anak

Sekolah ramah anak

SD Muhammadiyah Sapen

\begin{abstract}
ABSTRAK
Penelitian ini bertujuan untuk menggali informasi pelaksanaan pembelajaran untuk mewujudkan Sekolah Ramah Anak (SRA) di SD Muhammadiyah Sapen Yogyakarta. Pendekatan yang dilakukan adalah kualitatif. Perencanaan pembelajaran dilakukan dengan menyusun rencana pembelajaran yang memperhatikan hak-hak anak, yakni memperhatikan waktu bermain dan istirahat, merencanakan materi ajar yang sesuai dengan kondisi anak, lingkungan pembelajaran disetting untuk memungkinkan siswa belajar aktif. Untuk aspek pelaksanaan pembelajaran dilakukan dengan mengembangkan materi ajar yang tidak terbatas dalam buku teks, tetapi mengedepankan budaya lokal, melakukan pembelajaran dengan memperhatikan karakteristik siswa, melaksanakan pembelajaran menyenangkan, memanfaatkan lingkungan, pengembangan minat dan bakat anak, tersedia waktu bermain, beristirahat, dan berolahraga, siswa diberi kesempatan untuk mengapresiasi seni budaya lokal, penggunaan alat permainan edukatif, menciptakan suasana belajar yang mengembangkan aspek peduli lingkungan. Pada bagian penilaian, dilakukan dengan melaksanakan penilaian autentik dalam hasil dan proses pembelajaran. Dari berbagai temuan, untuk menciptakan SRA melalui pembelajaran yang masih perlu diperhatikan adalah layanan inklusi.
\end{abstract}

Keywords:
Child rights
Child-friendly school
Muhammadiya Sapen Primary
School

Keywords:

Child-friendly school School

\begin{abstract}
The implementation of child rights through child-friendly school. The research was aimed at revealing information related to instructional activities to implement student-friendly school at Muhammadiyah Sapen Primary School. It was approached qualitative descriptively. The research reveals that to ensure student-friendly school condition, it was through rigorous planning and instructional activities by considering students characteristics, developing teaching materials, setting class layout conducive to active learning, conducting joyful learning, outdoor activities, developing student potentials and interests, plotting time dedicated for playing, utilizing educative games, and caring environment, utilizing authentic assessment both on process and result of learning without comparing the results each other's. However, it needs special service for student with unique behavior to ensure that the condition is considered as studentfriendly school.
\end{abstract}




\section{Pendahuluan}

Pendidikan merupakan hak yang harus diperoleh setiap warga negara, termasuk anak-anak. Pendidikan merupakan sarana untuk mengembangkan minat dan bakat siswa sesuai dengan potensi yang dimilikinya. Hal tersebut sesuai dengan apa yang diatur dalam konstitusi Undang-Undang Dasar 1945 Pasal 28C bahwa "Setiap orang berhak mengembangkan diri melalui pemenuhan kebutuhan dasar, berhak mendapat pendidikan dan memperoleh manfaat dari ilmu pengetahuan dan teknologi, seni dan budaya, demi meningkatkan kualitas hidupnya dan demi kesejahteraan umat manusia. Ketentuan dalam konstitusi tersebut diatur pula dalam Undang-Undang Nomor 23 Tahun 2002 tentang Perlindungan Anak Pasal 9 ayat (1) yang menyebutkan bahwa "Setiap anak berhak memperoleh pendidikan dan pengajaran dalam rangka pengembangan pribadinya dan tingkat kecerdasannya sesuai dengan minat dan bakatnya."

Pengembangan bakat dan minat anak tidak dapat dilakukan dengan optimal tanpa adanya dukungan yang baik dari lingkungan sekitar, baik lingkungan keluarga, sekolah, maupun masyarakat. Tidak dapat dimungkiri bahwa lingkungan sekolah merupakan faktor yang memiliki andil dalam pemenuhan hak anak. Dalam hal ini tentu harapannya sekolah dapat memberikan layanan yang baik kepada anak demi berkembangnya anak secara optimal.

Pemerintah Daerah Kota Yogyakarta pun tidak ketinggalan dalam upaya menciptakan KLA. Kantor Pemberdayaan Masyarakat dan Perempuan Kota Yogyakarta mulai menyosialisasikan Peraturan Daerah Nomor 1 Tahun 2016 tentang Kota Layak Anak, guna menjamin terpenuhinya hak anak. Dalam Perda KLA, pemenuhan hak anak diarahkan melalui pengembangan sekolah ramah anak, pelayanan kesehatan ramah anak dan kampung ramah anak.

Dalam Peraturan Menteri Negara Pemberdayaan Perempuan dan Perlindungan Anak Republik Indonesia Nomor 8 Tahun 2014 tentang Kebijakan Sekolah Ramah Anak, dijelaskan bahwa dalam mewujudkan
Sekolah Ramah Anak (SRA) ada enam indikator yang dikembangkan untuk mengukur capaian SARA. Indikator tersebut meliputi: 1) kebijakan SRA, 2) pelaksanaan kurikulum, 3) pendidikan dan tenaga kependidikan terlatih hak-hak anak, 4) sarana dan prasarana SRA, 5) partisipasi anak, dan 6) partisipasi orang tua, lembaga masyarakat, dunia usaha, pemangku kepentingan lainnya, dan alumni. idealnya keenam indikator tersebut harus dipenuhi dalam rangka mewujudkan SRA.

Model SRA bukan hanya merupakan konsep abstrak atau metodologi semata. Konsep SRA merupakan prinsip pendidikan yang mengakui bahwa pendidikan yang berpusat pada anak merupakan bagian dari hak asasi manusia. Sekolah Ramah Anak pada prinsipnya merupakan hal penting yang harus diciptakan setiap saat. Konsep SRA diciptakan berdasarkan prinsip demi terealisasi nya hak anak atas pendidikan yang berkualitas (UNICEF, 2005, hal. 2) Dalam hal ini ditekankan bahwa menciptakan sekolah yang layak adalah hal penting untuk dilakukan.

Pada Peraturan Menteri Pemberdayaan Perempuan dan Perlindungan Anak Nomor 12 Tahun 2011 tentang Indikator Kota Layak Anak dijelaskan bahwa setiap anak mendapatkan akses pendidikan dan pelatihan yang berkualitas tanpa diskriminasi. Contohnya adalah mendorong sekolah inklusi; memperluas pendidikan kejuruan, non-formal dan informal; mendorong terciptanya sekolah ramah anak dengan mengaplikasikan konsep disiplin tanpa kekerasan, dan menjamin keamanan dan keselamatan perjalanan anak ke dan dari sekolah. Di samping itu juga dijelaskan bahwa lembaga pendidikan bertujuan untuk mengembangkan minat, bakat dan kemampuan anak serta mempersiapkan anak untuk bertanggung jawab kepada kehidupan yang toleran, saling menghormati dan bekerja sama untuk kemajuan dunia dalam semangat perdamaian.

Dalam Peraturan Menteri Negara Pemberdayaan Perempuan dan Perlindungan Anak Republik Indonesia Nomor 8 Tahun 
2014 tentang Kebijakan Sekolah Ramah Anak. Dalam peraturan tersebut dijelaskan bahwa Sekolah Ramah Anak yang selanjutnya disingkat SRA adalah satuan pendidikan formal, nonformal, dan informal yang aman, bersih dan sehat, peduli dan berbudaya lingkungan hidup, mampu menjamin, memenuhi, menghargai hak-hak anak dan perlindungan anak dari kekerasan, diskriminasi, dan perlakuan salah lainnya serta mendukung partisipasi anak terutama dalam perencanaan, kebijakan, pembelajaran, pengawasan, dan mekanisme pengaduan terkait pemenuhan hak dan perlindungan anak di pendidikan.

Kualitas SRA harus dievaluasi dari beberapa dimensi yaitu: a) berapa komposisi siswa laki-laki dan perempuan yang akan masuk ke sekolah, b) jumlah guru yang dapat memenuhi hak-hak mereka, c) pembelajaran yang dapat mempromosikan kesejahteraan dan kesehatan mereka, d) lingkungan yang kondusif untuk belajar, e) penghormatan guru terhadap hak dan kepentingan anak, f) metode pembelajaran yang berpusat pada anak, g) interaksi kelas dan manajemen sekolah, h) ruang kelas yang mendukung pembelajaran aktif, i) ketersediaan lingkungan, perlengkapan, fasilitas, dan layanan yang mendukung kebutuhan semua anak, dan j) pembelajaran yang tidak diskriminasi terhadap jenis kelamin, etnis, dan latar belakang sosial (UNICEF, 2005, hal. 4)

Berdasarkan penjelasan di atas, maka SRA merupakan satu lingkungan yang penting harus diperhatikan demi terpenuhinya hak dasar. SRA perlu mendapat perhatian dalam perwujudannya, karena mengingat salah satu fokus KLA adalah kluster pendidikan. Dalam Pasal 11 Peraturan Menteri Nomor 12 Tahun 2011 Pemberdayaan Perempuan dan Perlindungan Anak dijelaskan bahwa dalam kluster pendidikan salah satu hal yang harus dipenuhi adalah tersedia fasilitas untuk kegiatan kreatif ramah anak, di luar sekolah, yang dapat diakses semua anak. Dalam Permen Nomor 12 Tahun 2011 dijelaskan bahwa dalam kluster pendidikan dipastikan bahwa lembaga pendidikan bertujuan untuk mengembangkan minat, bakat dan kemampuan anak serta mempersiapkan anak untuk bertanggung jawab kepada kehidupan yang toleran, saling menghormati dan bekerja sama untuk kemajuan dunia dalam semangat perdamaian.

Di Indonesia kebijakan terkait dengan SRA dituangkan dalam Peraturan Menteri Negara Pemberdayaan Perempuan dan Perlindungan Anak Republik Indonesia Nomor 8 Tahun 2014 tentang Kebijakan Sekolah Ramah Anak. Dalam peraturan tersebut dijelaskan bahwa Sekolah Ramah Anak yang selanjutnya disingkat SRA adalah satuan pendidikan formal, nonformal, dan informal yang aman, bersih dan sehat, peduli dan berbudaya lingkungan hidup, mampu menjamin, memenuhi, menghargai hak-hak anak dan perlindungan anak dari kekerasan, diskriminasi, dan perlakuan salah lainnya serta mendukung partisipasi anak terutama dalam perencanaan, kebijakan, pembelajaran, pengawasan, dan mekanisme pengaduan terkait pemenuhan hak dan perlindungan anak di pendidikan.

Data di lapangan menunjukkan bahwa dalam upaya mewujudkan SRA, belum semua sekolah memenuhi indikator untuk disebut sebagai SRA. Berdasarkan hasil penelitian yang dilakukan (Maufur, 2014) menunjukkan data bahwa pelaksanaan sekolah ramah anak di lingkungan SMA Kota Tegal belum sepenuhnya dilaksanakan meskipun sudah dimaksimalkan Adapun strategi yang digunakan dalam mengembangkan strategi sekolah ramah anak memuat 4 unsur yaitu: perencanaan program sekolah yang sesuai dengan tahap-tahap pertumbuhan dan perkembangan peserta didik, lingkungan sekolah yang mendukung pertumbuhan dan perkembangan peserta didik, aspek sarana dan prasarana yang memadai dan sekolah juga menjamin hak partisipasi anak.

Salah satu komponen yang dijadikan tolok ukur ketercapaian SRA adalah dalam hal pembelajaran. Berdasarkan Peraturan Menteri Negara Pemberdayaan Perempuan dan Perlindungan Anak Republik Indonesia Nomor 8 Tahun 2014 tentang Kebijakan Sekolah Ramah Anak dalam komponen pembelajaran ada beberapa indikator yang 
harus dipenuhi untuk menjadi SRA, yaitu: 1) tersedianya dokumen kurikulum, 2) perencanaan pendidikan yang berbasis anak, 3) proses pembelajaran, dan 4) penilaian hasil belajar yang mengacu pada hak anak. Penciptaan iklim SRA ini penting dengan didasari pada pola pengalaman kehidupan sekolah orang-orang dan mencerminkan norma, tujuan, nilai, hubungan interpersonal, praktik belajar mengajar, dan struktur organisasi (Thapa, Cohen, Guffey, \& Higgins-D'Alessandro, 2013)

Berdasarkan data di lapangan SD Muhammadiyah Sapen merupakan salah satu sekolah dengan populasi siswa yang sangat besar yaitu sejumlah 1400an siswa. Rombongan belajar (rombel) pada sekolah ini juga termasuk besar, karena jumlah siswa dalam satu kelas antara 35-40 siswa. Jumlah rombel yang besar, tentunya akan menuntut keterampilan guru untuk tetap mampu melaksanakan pembelajaran yang sesuai dengan indikator-indikator SRA. Populasi siswa yang sangat besar, tentunya juga akan menuntut ketersediaan ruang indoor dan outdoor yang memadai untuk belajar. Ketersediaan ruang indoor dan outdoor juga menjadi salah satu indikator dalam pencapaian SRA. Berdasarkan masalahmasalah di atas, dalam penelitian ini hendak menggali berbagai upaya yang dilakukan sekolah dalam menciptakan sekolah ramah anak melalui pembelajaran.

\section{Metode}

Jenis penelitian ini adalah deskriptif dengan pendekatan kualitatif. Subjek penelitian atau informan terdiri dari adalah kepala sekolah, guru, dan siswa di SD Muhammadiyah Sapen Yogyakarta. Teknik pengumpulan data yang digunakan adalah observasi, wawancara, dan dokumentasi. Teknik pemeriksaan keabsahan data yang digunakan adalah teknik triangulasi metode. Teknik analisis yang digunakan dalam penelitian ini adalah teknik analisis induktif, yaitu analisis yang bertolak dari data dan bermuara pada simpulan-simpulan umum. Langkah-langkah analisis data tersebut meliputi: reduksi data, unifikasi dan kategorisasi, display data, dan penarikan kesimpulan.

\section{Hasil dan pembahasan}

Seiring dengan hadirnya peraturan tentang Sekolah Ramah Anak (SRA) yang tertuang dalam Peraturan Menteri PPPA No. 8 Tahun 2014 tentang Kebijakan Sekolah Ramah Anak, SD Muhammadiyah Sapen melakukan berbagai upaya untuk dapat mewujudkan sekolah yang ramah anak sesuai dengan indikator-indikator SRA yang ditetapkan dalam peraturan tersebut. Beberapa upaya sekolah dalam mewujudkan SRA dalam bidang pembelajaran diuraikan sebagai berikut:

\section{Dokumen kurikulum dan perencanaan pembelajaran berbasis hak anak}

Kurikulum merupakan bagian penting dalam proses pendidikan di sekolah. Setiap sekolah idealnya memiliki dokumen tentang kurikulum yang berlaku. Dokumen kurikulum yang seharusnya dimiliki setiap sekolah setidaknya dalam wujud silabus dan RPP. Dalam upaya menindaklanjuti indikator SRA yang tertuang dalam Peraturan Menteri PPPA No. 8 Tahun 2014 yang menjelaskan bahwa salah satu indikator SRA adalah memiliki dokumen kurikulum berbasis hak anak, maka SD Muhammadiyah Sapen memiliki kebijakan untuk merancang pemelajaran yang mengedepankan pemenuhan hak-hak anak. Dokumen kurikulum yang dimaksudkan dalam penelitian ini adalah silabus dan RPP.

Berdasarkan hasil penelitian diperoleh data bahwa bapak/ibu guru di SD Muhammadiyah Sapen wajib mengembangkan RPP sebagai pedoman dalam pelaksanaan pembelajaran di kelas. Silabus dan RPP yang dibuat diharapkan mampu mengarahkan guru untuk mengimplementasikan pembelajaran yang menyenangkan bagi anak. Dalam perencanaan pembelajaran bapak ibu guru diharapkan untuk mempertimbangkan tatang berabagai hal agar pelaksanaan pembelajaran di kelas tidak mudah membosankan, tidak memaksa anak, tidak membuat anak tertekan, tetap memperhatikan kebutuhan anak akan 
istirahat, makan, dan minum. Kebijakan lain tentang upaya sekolah dalam SRA dijelaskan oleh Kepala Sekolah bahwa guru kelas di SD Muhammadiyah Sapen diberikan kebebasan untuk melakukan perencanaan pengelolaan kelas disesuaikan dengan kebutuhan dan karakteristik belajar siswa. Penciptaan iklim kelas yang bersahabat ini meliputi setting tempat duduk, pernak-pernik dinding kelas, dan setting berbagai peralatan kelas. I

Perencanaan pembelajaran selalu memperhatikan pemenuhan hak-hak anak yang dituangkan dalam silabus dan RPP. Secara implisit RPP yang dikembangkan bapak/ibu guru dibuat sesuai dengan kemampuan siswa untuk mengikuti pelajaran. Beberapa pertimbangan yang dijadikan dasar bagi bapak/ibu guru dalam membuat RPP adalah waktu belajar. Dalam sehari waktu belajar siswa selalu diselingi dengan istirahat. Waktu istirahat ini diberikan agar otak anak tidak terus menerus belajar. Mereka memiliki kesempatan untuk bermain dengan temanteman, dan juga makan dan minum. Pemenuhan hal anak yang dituangkan dalam silabus dan RPP ini juga dilakukan ketika bapak/ibu guru menyusun langkah-langkah pembelajaran. Menurut data hasil wawancara dijelaskan bahwa bapak/ibu guru memilih model-model pembelajaran yang menyenangkan bagi anak-anak. Berdasarkan data hasil wawancara dengan guru juga dijelaskan bahwa guru memiliki otoritas untuk menciptakan suasana kelas yang mempedulikan hak anak. Pengaturan situasi kelas diserahkan kepada guru kelas masingmasing dengan melibatkan anak-anak.

Perencanaan pembelajaran yang dibuat oleh masing-masing guru kelas di SD Muhammadiyah Sapen dilakukan dengan memperhatikan aspek kebutuhan anak dalam hal bermain, dan beristirahat. Hal ini ditandai dengan adanya kegiatan pembelajaran yang memberikan waktu untuk anak beristirahat dan bermain. Hal ini sesuai dengan apa yang tertuang dalam Peraturan Menteri PPPA No. 8 Tahun 2014 tentang Kebijakan Sekolah Ramah Anak, salah satunya bahwa dalam menyusun perencanaan pembelajaran perlu memperhatikan waktu untuk istirahat, memungkinkan proses pembelajaran yang aktif, non diskriminatif, bebas dari unsur kekerasan, pornografi, dan terorisme.

\section{Proses pembelajaran}

Proses pembelajaran di sekolah merupakan tanggung guru untuk melaksanakannya. Tentunya dalam pelaksanaan pembelajaran ini guru bertolak pada kebijakan sekolah agar tidak menyimpang dari visi misi SD Muhammadiyah Sapen. Guru tidak hanya berpedoman pada materi ajar yang ada dalam buku siswa. Dalam proses pembelajaran guru dapat mengembangkan bahan ajar sendiri sesuai dengan tingkat perkembangan siswa, dan juga lingkungan belajarnya. Guru dalam pengembangan materi ajar tidak membedabedakan jenis kelamin, suku bangsa, status sosial ekonomi, dan tempat tinggal. Pengembangan materi ajar sering dilakukan guru dengan mengaitkan kompetensi dasar yang sedang diajarkan dengan kondisi riil siswa.

Dalam menyampaikan materi, guru banyak melakukan pengembangan materi yang lebih sesuai dengan karakteristik dan lingkungan belajar siswa. Sebagai contoh pada saat observasi pembelajaran di kelas IV, guru pada saat itu menjelaskan tentang jam gadang. Dalam menjelaskan materi ini guru membuat teks cerita tentang jam gadang dengan mengaitkan pada aktivitas siswa pada saat liburan. Kebetulan pada saat liburan ada siswa yang memiliki sanak keluarga di Padang. Siswa tersebut dipesankan guru untuk melihat jam gadang. Pada saat sampai pada materi jam gadang, siswa diminta bercerita tentang jam gadang dan berbagai hal tentang Kota Padang. Siswa sangat antusias mengikuti pembelajaran terkait dengan materi jam gadang.

Hasil observasi pembelajaran di kelas IV tersebut didukung juga oleh data hasil observasi pembelajaran di kelas II. Guru di kelas II yang pada saat observasi pembelajaran mengajarkan tentang berbagai macam permainan tradisional, mengajarkan materi ajar tidak sebatas yang ada di buku. Guru dalam pembelajaran ini mengembangkan materi dengan 
memanfaatkan lingkungan belajar yang dekat dengan siswa. Permainan tradisional yang ada di lingkungan siswa, seperti dakon, enggrang, dan yoyo digunakan untuk menyampaikan materi tentang permainan tradisional.

Mengenai pengembangan minat dan bakat, Sekolah Dasar Muhammadiyah Sapen merupakan sekolah yang banyak mengembangkan minat dan bakat siswa. Pengembangan minat dan bakat ini dilakukan melalui dua kebijakan yaitu pembinaan prestasi siswa dan ekstrakurikuler. Berdasarkan hasil wawancara dengan kepala sekolah, guru, dan siswa pengembangan minat dan bakat yang dilaksanakan di SD Muhammadiyah Sapen meliputi basket, futsal, pantomim, puisi, presenter, dai cilik, MTQ, band, tari, robotika, paduan suara, vocal group, dan sebagainya. Penelusuran minat bakat di SD Muhammadiyah Sapen dilakukan melalui jalur penyaringan dari hasil lomba antar kelas yang diadakan pada saat peringatan hari besar, misalnya hari besar agama islam, perayaan hari kemerdekaan, dan sebagainya. Penjaringan minat bakat juga dilakukan melalui audiensi. Kegiatan ini diawali dengan mengedarkan daftar isian kepada masing-masing siswa untuk memilih minat dan bakat yang akan dikembangkan. Edaran ini diisi bersama-sama dengan orang tua. Maksud pengisian dilakukan dengan orang tua agar kegiatan yang dipilih anak benar-benar sesuai dengan minat dan bakat yang akan dikembangkan.

Mengenai ketersediaan waktu untuk istirahat dan kegiatan bermain, merupakan salah satu bagian yang diperhatikan oleh pihak SD Muhammadiyah Sapen. Berdasarkan hasil penelitian diperoleh data bahwa dalam sehari-harinya anak-anak mempunyai waktu istirahat dan bermain di sela-sela kegiatan belajar. Untuk anak-anak kelas 1 dan 2 memiliki waktu istirahat sekali pada pukul 09.00-09.30 Pada saat istirahat ini anak diberikan kesempatan untuk bermain dengan teman-temannya yang satu kelas, atau bahkan berlainan kelas. Pada jam istirahat ini pula anak-anak diberi kesempatan untuk makan snack dan minum. Adapun untuk kelas 3, 4, 5, dan 6 istirahat diberikan dua kali, yaitu pada pukul 09.30 dan saat menjelang salat zuhur. Pada istirahat pertama anak-anak diberikan kesempatan bermain dengan anakanak lain yang mungkin tidak satu kelas, serta makan snack. Pada saat istirahat ke dua waktunya lebih panjang Karen anak-anak akan melaksanakan salat zuhur dan makan siang.

Menanggapi tentang pemberian waktu istirahat ini, siswa merasa senang karena bisa bertemu dengan teman-teman lain yang beda kelas. Di samping itu mereka juga memiliki kesempatan bermain untuk menghilangkan kejenuhan yang ada saat proses pembelajaran di kelas. Menurut keterangan siswa senang rasanya bermain dengan teman-teman lain kelas saat istirahat karena jadi punya teman yang lebih banyak.

Keterlibatan peserta didik dalam mengapresiasi kehidupan seni dan budaya Sekolah Dasar Muhammadiyah Sapen dengan memberi kesempatan kepada siswa untuk terlibat aktif dalam mengapresiasi siswa dalam bidang seni dan budaya ini dijadikan agenda yang rutin dilaksanakan setiap tahun. Kegiatan apresiasi seni ini dilakukan pada saat memperingati hari Kartini, dan peringatan Hari Ulang Tahun Kota Yogya. Pada kegiatan tersebut anak-anak diwajibkan mengenakan busana daerah. Beberapa kegiatan yang dilakukan di sekolah antara lain lomba menyanyi, lomba menghias tumpeng, lomba mewarnai dan menggambar, lomba baca puisi, lomba denok dan thole, dan berbagai jenis lomba lainnya. Kegiatan ini diwarnai dengan pernak pernik yang menggambarkan nuansa budaya Jawa. Hal ini dimaksudkan agar siswa memiliki kecintaan terhadap budaya Jawa.

Dalam proses pembelajaran di sekolah, salah satu yang tidak boleh dilupakan adalah penggunaan alat permainan edukatif. Idealnya alat permainan yang digunakan adalah alat-alat yang aman bagi anak baik dari bentuknya, maupun bahan pembuatnya. Menurut hasil wawancara dengan kepala sekolah, dan guru SD Muhammadiyah Sapen memiliki alat permainan edukatif yang memenuhi kriteria standard nasional. Alat permainan tersebut dari sisi bentuk dan bahan 
pembuatnya nyaman digunakan untuk anak. Alat-alat tersebut banyak digunakan untuk pembelajaran IPA, matematika, dan olah raga.

Penggunaan alat permainan yang mendukung proses pembelajaran oleh guru dilakukan dalam berbagai bentuk kegiatan. Sebagai contoh pada pembelajaran matematika guru menggunakan busur derajat, dan penggaris. Pada pembelajaran IPA banyak guru yang menggunakan alat peraga IPA yang sesuai dengan materi pembelajaran. Begitu juga saat mata pelajaran Olah Raga guru banyak menggunakan peralatan, misalnya bola sepal, bola kasti, bola basket, dan peralatan olah raga lainnya.

Pembiasaan peduli dan berbudaya lingkungan dalam pembelajaran di SD Muhammadiyah Sapen Yogyakarta dilakukan dengan cara secara periodic diadakan kegiatan outbond. Kegiatan ini dilakukan satu kali dalam satu semester. Berdasarkan data hasil penelitian menunjukkan bahwa kegiatan outbond dimaksudkan untuk mendekatkan siswa kepada alam. Dalam kegiatan outbond ini ditanamkan nilai-nilai peduli lingkungan. Anak-anak secara bebas dapat merasakan udara yang bersih dan sejuk. Dari situlah ditanamkan kepada anak-anak tentang sikap yang harus dikembangkan untuk menjaga kelestarian lingkungan alam. Lokasi outbond yang pernah digunakan antara lain di Grogol, Margoagung Seyegan, Sleman dan Desa Wisata Kelor, Pakem, Sleman.

Kegiatan outdoor learning benar-benar mendekatkan siswa kepada alam. Sebagai contoh kegiatan yang dilakukan adalah meniti di atas air, berenang, dan aktivitas lain yang bersinggungan dengan alam. Dalam kegiatan ini juga dikembangkan rasa percaya diri siswa untuk melaksanakan beragam aktivitas menantang. Ada kalanya saat pertama kalinya harus mencoba suatu kegiatan anak-anak tidak berani, akan tetapi setelah melihat temannya dan juga atas bantuan instrukturnya lama-lama muncul keberanian dan percaya diri. Dalam kegiatan ini juga dikembangkan kebiasaan saling tolong menolong dan kerja sama. Beberapa kegiatan sengaja dibuat secara berkelompok agar antar siswa muncul motivasi untuk kerja sama dan tolong menolong.

Ketersediaan sarana pembelajaran merupakan salah satu pendukung keberhasilan proses belajar mengajar di sekolah. Ruang belajar itu dapat berupa sarana indoor maupun outdoor yang dapat mendukung keterlaksanaan proses belajar mengajar. Sarana indoor yang dimiliki oleh SD Muhammadiyah Sapen sangatlah beragam. Berdasarkan hasil wawancara dengan kepala sekolah dan guru, ruang indoor yang digunakan untuk proses pembelajaran meliputi ruang kelas, laboratorium TIK, ruang multimedia, ruang musik, ruang laboratorium IPA, sarana ibadah, dan perpustakaan. Adapun ruang outdoor berupa halaman sekolah yang sering dimanfaatkan untuk olah raga. Sekarang ini SD Muhammadiyah Sapen sedang mengembangkan ruang outdoor di daerah Gambiran Kota Yogyakarta. Ruang outdoor yang dibangun di sana direncanakan untuk digunakan sebagai sarana pembelajaran setiap satu minggu sekali secara bergiliran.

Upaya menciptakan SRA dalam pelaksanaan pembelajaran dilakukan dengan salah satunya dengan pengembangan bahan ajar yang tidak terbatas pada penggunaan buku teks yang disediakan sekolah, tetapi guru mencari bahan ajar yang lebih kontekstual dengan lingkungan dan kondisi siswa. Guru banyak memanfaatkan lingkungan sebagai sumber belajar dalam hal ini. Prastowo (2012, hal. 34) menjelaskan bahwa lingkungan merupakan salah satu kelompok sumber belajar yang dapat dimanfaatkan untuk pengembangan bahan ajar. Lingkungan yang dimaksudkan di sini dapat berupa lingkungan alam, sosial, maupun buatan. Di samping itu dalam mengembangkan bahan ajar, guru juga memanfaatkan peristiwa yang terjadi di sekitar anak.

Ketika proses pembelajaran guru juga memberikan kesempatan kepada peserta didik untuk melakukan apresiasi terhadap budaya lokal melalui berbagai kegiatan. Pembelajaran yang mengembangkan 
apresiasi terhadap budaya lokal ini dilakukan dalam berbagai bentuk di antaranya dikaitkan dengan tema yang sedang dibahas di sekolah tersebut serta event yang sedang terjadi. Dalam melaksanakan pembelajaran guru juga memanfaatkan lingkungan belajar, baik indoor maupun outdoor. Majid (2007, hal. 170 )menjelaskan bahwa lingkungan dapat dikategorikan ke dalam sumber belajar yang dapat dimanfaatkan untuk proses pembelajaran. Menurutnya Tempat atau lingkungan alam sekitar yaitu dimana saja seseorang dapat melakukan belajar atau proses perubahan tingkah laku maka tempat itu dapat dikategorikan sebagai tempat belajar yang berarti sumber belajar, misalnya perpustakaan, pasar, museum, sungai, gunung, tempat pembuangan sampah, kolam ikan, dan sebagainya.

\section{Penilaian hasil belajar yang mengacu pada hak anak}

Berdasarkan data hasil penelitian diperoleh data bahwa penilaian dilaksanakan berbasis proses dan mengedepankan penilaian autentik. Penilaian proses ini dilakukan ketika siswa diberikan tugas maka guru akan menilai sejak persiapan, pelaksanaan kerja, dan hasil kerja. Pada tahap persiapan guru akan melihat sejauh mana kesiapan siswa dalam mempersiapkan segala hal terkait dengan pengerjaan tugas tersebut. Misalnya pada saat akan membuat origami, maka guru melihat kesiapan masing-masing siswa terkait dengan persiapan kertas, gunting, dan lem. Selanjutnya guru melakukan penilaian dalam proses pengerjaan origami tersebut. Penilaian meliputi kemandirian siswa dalam pengerjaannya. Sebagai contoh siswa yang berhasil membuat origami sendiri tentunya berbeda bobot penskorannya dengan siswa yang berhasil membuat origami dengan bantuan. Penilaian berikutnya yaitu pada hasil akhir. Penilaian ini ditujukan pada hasil akhir pengerjaan origami yang meliputi aspek kerapian, bentuk, dan kebersihan. Dalam pelaksanaan penilaian belajar dilakukan dengan memperhatikan prinsip penilaian autentik. Majid (2007, hal. 186) menjelaskan bahwa penilaian autentik adalah proses pengumpulan informasi oleh guru tentang perkembangan dan pencapaian pembelajaran yang dilakukan siswa melalui berbagai teknik yang mampu mengungkapkan, membuktikan atau menunjukkan secara tepat bahwa tujuan pembelajaran dan kompetensi telah benarbenar dikuasai dan dicapai. Dalam proses penilaian guru menggunakan teknik dan instrumen yang bervariasi sesuai dengan kompetensi yang hendak diukur.

Penilaian hasil belajar juga dilakukan dengan tidak membandingkan hasil belajar antara siswa satu dengan yang lain. Hal ini dilakukan guna menghindari perilaku anak untuk melabel dirinya sebagai orang yang lebih superior dibandingkan dengan teman lainnya. Dikhawatirkan jika terjadi pelabelan pada siswa terutama dari sisi kognitif akan memunculkan sikap eksklusif tertentu de kalangan siswa.

\section{Simpulan}

Upaya mewujudkan SRA melalui pembelajaran di SD Muhammadiyah Sapen dilakukan dalam suluruh aspek pembelajaran mulai dari perencanaan, pelaksanaan, dan evaluasi hasil belajar. Dalam perencanaan pembelajaran dilakukan dengan cara menyusun rencana pembelajaran yang memperhatikan hak-hak anak, di antaranya memperhatikan waktu bermain dan istirahat, merencanakan materi ajar yang sesuai dengan kondisi anak, lingkungan pembelajaran didesain untuk memungkinkan siswa belajar aktif. Untuk aspek pelaksanaan pembelajaran dilakukan dengan mengembangkan materi ajar yang tidak terbatas dalam buku teks, tetapi mengedepankan budaya lokal, melakukan pembelajaran dengan memperhatikan berbagai karakteristik peserta didik, melaksanakan pembelajaran yang menyenangkan, memanfaatkan lingkungan indoor dan outdoor, pengembangan minat dan bakat anak, tersedia waktu bermain, beristirahat, dan berolahraga, siswa diberi kesempatan untuk mengapresiasi seni budaya lokal, penggunaan alat permainan edukatif, menciptakan suasana belajar yang mengembangkan aspek peduli lingkungan. Pada bagian penilaian, dilakukan dengan melaksanakan penilaian autentik dalam hasil 
dan proses pembelajaran, penilaian dilakukan tidak dengan membandingkan antar peserta didik. Dari berbagai temuan penelitian di SD Muhammadiyah Sapen untuk menciptakan SRA melalui pembelajaran yang masih perlu diperhatikan adalah layanan untuk anak-anak yang berperilaku mengarah pada keunikan tertentu

\section{Referensi}

Majid, A. (2007). Perencanaan pembelajaran pengembangan ttandar kompetensi guru. Bandung: Remaja Rosdakarya.

Maufur. (2014). Strategi program pengembarngan sekolah ramah anak di SMA Kota Tegal dalam standar pendidikan nasional. Tegal.

Prastowo, A. (2012). Panduan kreatif membuat bahan ajar inovatif. Yogyakarta: Diva Press.

Peraturan Menteri Pemberdayaan Perempuan dan Perlindungan Anak Nomor 11 Tahun 2011 Tentang Pengembangan Kebijakan Kota Layak Anak.

Peraturan Menteri Pemberdayaan Perempuan dan Perlindungan Anak Nomor 12 Tahun 2011 Tentang Pengembangan Indikator Kota Layak Anak.

Peraturan Menteri Pemberdayaan Perempuan dan Perlindungan Anak Nomor 8 Tahun 2014 Tentang Kebijakan Sekolah Ramah Anak.

Thapa, A., Cohen, J., Guffey, S., \& HigginsD'Alessandro, A. (2013). A review of school climate research. Review of Educational Research, 83(3), 357385.

https://doi.org/10.3102/00346543134 83907

UNICEF. (2005). Manual child-friendly school. New York: UNICEF. 